\title{
EFEKTIFITAS EKSTRAK DAUN KRINYU (Chromolaena odorata) DAN TEKI (Cyperus rotundus L.) TERHADAP PERTUMBUHAN Colletotrichum musae PATOGEN ANTRAKNOSA PADA PISANG (Musa paradisiacal L.)
}

\author{
Yanuar Muhammad Nur, Efri \& Radix Suharjo \\ Jurusan Agroteknologi, Fakultas Pertanian, Universitas Lampung \\ Jl. Prof. Soemantri Brojonegoro, No. 1 Bandar Lampung 35145 \\ Email: yanumuhammad32@gmail.com
}

\begin{abstract}
ABSTRAK
Penurunan jumlah ekspor pisang disebabkan oleh kualitas buah pisang yang kurang baik akibat serangan penyakit antraknosa. Hingga saat ini fungisida sintetik yang kurang ramah lingkungan masih digunakan untuk mengendalikan penyakit antraknosa sehingga perlu adanya fungisida alternatif yang lebih ramah lingkungan. Penelitian ini dilaksanakan pada bulan April-Juni 2016 di Laboratorium Hama Penyakit Tanaman, Universitas Lampung. Tujuan penelitian ini adalah untuk mengetahui efektifitas ekstrak daun krinyu dan teki sebagai fungisida nabati dalam menekan pertumbuhan $C$. musae patogen antraknosa pada pisang. Penelitian ini menggunakan rancangan acak lengkap dengan tujuh perlakuan dan empat ulangan. Perlakuan dibagi menjadi kontrol, krinyu fraksi air, krinyu fraksi alkohol, teki fraksi air, teki fraksi alkohol, krinyu tanpa fraksinasi dan teki tanpa fraksinasi. Selanjutnya dilakukan uji beda nyata terkecil (BNT). Hasil penelitian menunjukkan bahwa perlakuan ekstrak krinyu tanpa fraksinasi lebih efektif menekan pertumbuhan dan pembentukan spora C. musae baik secara in vitro maupun in vivo.
\end{abstract}

Kata kunci : Colletotrichum musae, krinyu, pisang, teki

\section{PENDAHULUAN}

Di Indonesia, pisang memiliki produksi yang tinggi dibandingkan dengan buah yang lain. Akan tetapi secara umum produktivitas pisang yang dikembangkan masyarakat Indonesia masih sangat rendah. Kesenjangan produktivitas tersebut terutama disebabkan teknik budidaya tidak tepat dan tingginya gangguan hama dan penyakit terutama oleh serangan penyakit pascapanen seperti antraknosa. Penyebab penyakit antraknosa adalah Colletotrichum musae (Semangun, 1996)

Pengendalian penyakit antraknosa biasanya dilakukan dengan menggunakan fungisida sintetik. Namun demikian, dampak yang ditimbulkan akibat penggunakan fungisida sintetik ini adalah terganggunya lingkungan seperti timbulnya resistensi patogen, terbunuhnya organisme non-target, residu pada makanan serta membahayakan bagi kesehatan manusia. Untuk mengurangi dampak negatif dalam pengendalian penyakit antraknosa, salah satunya dengan menggunakan fungisida nabati.

Tumbuhan yang dapat digunakan sebagai pestisida nabati diantaranya adalah tumbuhan krinyu (Chromolaena odorata) dan teki (Cyperus rotundus). Ekstrak daun krinyu ini dilaporkan bersifat anti jamur terhadap Aspergillus niger (Owolabi, dkk., 2010) dan
Drechslera heveaeatau bercak daun (Ogbebor dan Adekunle, 2008). Oleh karena itu pada penelitian ini digunakan ekstrak dari daun krinyu dan teki. Penelitian ini bertujuan untuk mengetahui efektivitas ekstrak daun krinyu dan teki sebagai fungisida nabati dalam menekan pertumbuhan $C$. musae penyebab antraknosa pada pisang secara in vitro dan in vivo.

\section{BAHAN DAN METODE}

Penelitian ini dilakukan di Laboratorium Penyakit Tanaman Fakultas Pertanian Universitas Lampung dan telah dilaksanakan pada bulan April sampai dengan Juni 2016. Penelitian ini dibagi menjadi dua sub percobaan yaitu pengujian secara in-vitro dan dilanjutkan pengujian secara in vivo pada ekstrak yang efektif menekan pertumbuhan Colletotrichum musae pada sub percobaan in vitro yang terdiri atas 7 perlakuan dengan 4 ulangan untuk masing-masing perlakuan. Perlakuan masing-masing sub percobaan disusun dalam Rancangan Acak Lengkap (RAL). Uji lanjut yang digunakan yaitu uji beda nyata terkecil (BNT) pada taraf $5 \%$.

\section{HASIL DAN PEMBAHASAN}

Hasil penelitian menunjukkan bahwa perlakuan ekstrak krinyu tanpa fraksinasi merupakan perlakuan 
yang terbaik dalam menekan pertumbuhan Colletotrichum musae. Ekstrak yang dibuat tanpa fraksinasi memiliki kandungan senyawa yang bersifat polar dan non-polar. Dengan adanya gabungan dari senyawa tersebut maka perlakuan krinyu tanpa fraksinasi memiliki efek yang lebih baik dalam menekan pertumbuhan dan pembentukan spora $C$. musae. Perlakuan krinyu tanpa fraksinasi memiliki senyawasenyawa yang kompleks bila dibandingkan dengan perlakuan lainnya yang hanya memiliki senyawasenyawa yang larut dalam air atau alkohol saja.

Perlakuan krinyu tanpa fraksinasi memiliki senyawa-senyawa yang kompleks bila dibandingkan dengan perlakuan lainnya yang hanya memiliki senyawasenyawa yang larut dalam air atau alkohol saja. Tumbuhan krinyu memiliki kandungan senyawa antara lain fenol, alkaloid, triterpenoid/steroid, monoterpen, seskuiterpen, tanin, saponin, flavonoid dan kuinon (Hadi, dkk., 2000). Sedangkan Teki memiliki kandungan senyawa metabolik berupa alkaloid, sineol dan minyak atsiri (Jawetz, dkk., 2008).

Senyawa yang efektif berperan dalam menekan pertumbuhan $C$. musae adalah senyawa yang memiliki sifat antifungi yaitu alkaloid yang mempunyai aktifitas antimikroba dengan menghambat esterase, DNA, RNA polimerase dan respirasi sel serta berperan dalam

Tabel 1. Pengaruh ekstrak terhadap rata-rata diameter koloni $C$. musae pada media PDA.

\begin{tabular}{|c|c|c|c|c|c|c|c|c|c|}
\hline \multirow{2}{*}{ Perlakuan } & \multicolumn{9}{|c|}{ Rata-rata diameter koloni $C$. musae $(\mathrm{cm})$ pada hari ke- } \\
\hline & $2 \mathrm{hsi}$ & $3 \mathrm{hsi}$ & 4 hsi & 5 hsi & 6 hsi & 7 hsi & 8 hsi & 9 hsi & 10 hsi \\
\hline P1 Kontrol & $2,20 \mathrm{a}$ & $2,84 a$ & $3,38 \mathrm{a}$ & $3,70 \mathrm{a}$ & $3,83 \mathrm{bc}$ & $4,02 \mathrm{~b}$ & $4,22 b$ & $4,34 \mathrm{c}$ & $4,43 b$ \\
\hline P2 Krinyu fraksi air & $2,12 \mathrm{ab}$ & $2,84 a$ & $3,45 a$ & $4,02 \mathrm{a}$ & $4,62 \mathrm{a}$ & $4,79 \mathrm{a}$ & $5,44 a$ & $5,71 \mathrm{a}$ & $5,72 \mathrm{a}$ \\
\hline P3 Krinyu fraksi alkohol & $1,97 \mathrm{bc}$ & $2,58 \mathrm{a}$ & $3,35 \mathrm{a}$ & $3,80 \mathrm{a}$ & $4,30 \mathrm{a}$ & $4,79 \mathrm{a}$ & $5,15 \mathrm{a}$ & $5,30 \mathrm{a}$ & $5,44 \mathrm{a}$ \\
\hline P4 Teki fraksi air & $1,96 \mathrm{c}$ & $2,52 b$ & $3,12 \mathrm{ab}$ & $3,54 \mathrm{ab}$ & $3,68 \mathrm{c}$ & $3,95 b$ & $4,17 \mathrm{~b}$ & $4,25 b$ & $4,46 b$ \\
\hline P5 Teki fraksi alkohol & $1,90 \mathrm{c}$ & $2,52 b$ & $3,08 b$ & $3,51 b$ & $3,67 \mathrm{c}$ & $3,94 b$ & $4,17 \mathrm{~b}$ & $4,32 \mathrm{~b}$ & $4,48 b$ \\
\hline P6 Krinyu tanpa fraksinasi & $1,80 \mathrm{c}$ & $2,12 \mathrm{c}$ & $2,31 \mathrm{c}$ & $2,45 \mathrm{c}$ & $2,75 d$ & $2,79 \mathrm{c}$ & $2,84 \mathrm{c}$ & $2,92 \mathrm{c}$ & $2,98 \mathrm{c}$ \\
\hline P7 Teki tanpa fraksinasi & $1,96 \mathrm{c}$ & $2,72 \mathrm{ab}$ & $3,42 \mathrm{a}$ & $2,45 \mathrm{a}$ & $4,14 a b$ & $4,45 \mathrm{ab}$ & $4,70 \mathrm{ab}$ & $4,90 \mathrm{ab}$ & $5,08 \mathrm{ab}$ \\
\hline Nilai BNT & 0,11 & 0,20 & 0,34 & 0,48 & 0,53 & 0,64 & 0,74 & 0,79 & 0,84 \\
\hline
\end{tabular}

Keterangan: Angka yang diikuti oleh huruf yang sama pada kolom yang sama tidak berbeda nyata pada uji lanjut BNT taraf 5\%

Tabel 2. Pengaruh ekstrak krinyu dan teki terhadap rata-rata kerapatan spora C. musae pada 10 hsi.

\begin{tabular}{lc}
\hline Perlakuan & Kerapatan spora $10^{5} \mathrm{ml}^{-1}$ \\
\hline P1 Kontrol & $1,30 \mathrm{c}$ \\
P2 Krinyu fraksi air & $6,60 \mathrm{a}$ \\
P3 Krinyu fraksi alkohol & $3,43 \mathrm{~b}$ \\
P4 Teki fraksi air & $3,18 \mathrm{~b}$ \\
P5 Teki fraksi alkohol & $0,68 \mathrm{c}$ \\
P6 Krinyu tanpa fraksinasi & $0,53 \mathrm{c}$ \\
P7 Teki tanpa fraksinasi & $0,98 \mathrm{c}$ \\
\hline Nilai BNT & 0,76 \\
\hline
\end{tabular}

Keterangan: Angka yang diikuti oleh huruf yang sama pada kolom yang sama tidak berbeda nyata pada uji lanjut BNT taraf 5\% 
interkalasi DNA (Rizky, 2012). Sedangkan sebagai antifungi secara mekanisme kerja menghambat biosintesis asam nukleat (Kusumaningtyas, dkk., 2008). Senyawa flavonoid terdapat pada tumbuhan berperan sebagai antifungi, antivirus, antimikroba, antikanker dan antiinsektisida (Kristanti, 2008). Flavonoid yang berperan sebagai antijamur yaitu dengan cara denaturasi protein, mengganggu lapisan lipid dan mengakibatkan kerusakan dinding sel (Gholib, 2009).

Saponin mempunyai efek antibakteri dan antijamur. Saponin berperan sebagai antijamur dengan cara mengakibatkan sel mikroba lisis, yaitu dengan mengganggu stabilitas membran selnya (Wulansari, 2009). Pengaruh senyawa triterpenoid/steroid sebagai antijamur yang terdapat pada tumbuhan krinyu terhadap C. musae adalah dengan cara menghambat pertumbuhan jamur, baik melalui membran sitoplasma maupun mengganggu pertumbuhan dan perkembangan spora jamur (Ismaini, 2011).

Senyawa yang larut dalam alkohol dan air adalah senyawa flavonoid. Senyawa ini merupakan senyawa polar. Sedangkan saponin merupakan senyawa yang larut dalam air dan bersifat polar. Senyawa steroid adalah senyawa non-polar yang larut dalam air maupun alkohol. Senyawa alkaloid merupakan senyawa yang hanya dapat larut dalam pelarut organik seperti eter dan memiliki sifat non-polar (Harborne, 1987), dengan kata lain senyawa alkaloid hanya ada pada perlakuan ekstrak krinyu tanpa fraksinasi dan teki tanpa fraksinasi.

Dari pernyataan diatas dapat dikatakan bahwa ekstrak krinyu tanpa fraksinasi memiliki semua kandungan senyawa yang berperan sebagai antijamur tersebut. Sedangkan pada perlakuan ekstrak yang lain hanya memiliki beberapa senyawa saja, sehingga kurang mampu menekan pertumbuhan dan sporulasi C. musae.

Ekstrak krinyu juga dilaporkan bersifat anti jamur terhadap Apergillusniger (Owolabi, dkk., 2010), dan Drechslera heveae (Ogbebor dan Adekunle, 2008). Penelitian sebelumnya yang dilakukan oleh Panggabean (2009) menyatakan bahwa krinyu efektif menghambat perkembangan Phytophthora palmivora. Menurut Panggabean, krinyu merupakan salah satu jenis

Tabel 3. Hasil perbandingan masing-masing perlakuan dengan perlakuan kontrol pada pengaruh ekstrak terhadap rata-rata diameter koloni dan kerapatan spora C. musae.

\begin{tabular}{lll}
\hline Perlakuan & Diameter koloni & Kerapatan spora \\
\hline p2 krinyu fraksi air & Memacu & Memacu \\
p3 krinyu fraksi alcohol & Memacu & Memacu \\
p4 teki fraksi air & Menekan $(* *)$ & Memacu \\
p5 teki fraksi alcohol & Menekan $(* * * *)$ & Tidak Berpengaruh \\
p6 krinyu tanpa fraksinasi & Menekan $(* * * * * *)$ & Tidak Berpengaruh \\
p7 teki tanpa fraksinasi & Menekan $(*)$ & Tidak Berpengaruh \\
\hline
\end{tabular}

Keterangan: $(* *)=$ efektif menekan hingga hari ke-3 setelah inokulasi, $(* * * *)=$ efektif menekan hingga hari ke-5 setelah inokulasi, $(* * * * * * *)=$ efektif menekan hingga hari ke-8 setelah inokulasi, $(*)=$ efektif menekan hingga hari ke-2 setelah inokulasi

Tabel 4. Hasil percobaan in vivo pada perlakuan P1 (kontrol) dan P6 (krinyu tanpa fraksinasi).

\begin{tabular}{lc}
\hline Perlakuan & Persentase keparahan penyakit $(\%)$ \\
\hline P1 Kontrol & $100 \mathrm{a}$ \\
P6 Krinyu tanpa fraksinasi & $82,75 \mathrm{~b}$ \\
\hline Nilai BNT & 11,39 \\
\hline
\end{tabular}

Keterangan: Angka yang diikuti oleh huruf yang sama pada kolom yang sama tidak berbeda nyata pada uji lanjut BNT taraf 5\% 
tumbuhan yang dapat digunakan sebagai bahan biopestisida untuk menghambat perkembangan organisme pengganggu tanaman termasuk jamur Phytophthora palmivora yang menyebabkan penyakit busuk buah kakao.

Pertumbuhan dan sporulasi C. musae pada perlakuan teki fraksi air dan teki tanpa fraksinasi yang tidak terlalu efektif menghambat dikarenakan C. musae merupakan patogen yang telah terbiasa hidup pada media yang mengandung senyawa yang diduga sebagai senyawa antijamur yang terdapat dalam ekstrak tersebut. C. musae menyerang tanaman pisang pada bagian daun, buah yang masih muda maupun yang sudah tua (Cahyono, 2009).

Getah pisang mengandung senyawa saponin, flavonoid, tannin dan alkaloid (Prasetyo, 2008). Senyawa flavonoid terdapat dalam berbagai bagian tanaman pisang (Imam, 2011).Penelitian lain yang dilakukan oleh Dinastutie, dkk. (2015) menyatakan ekstrak kulit pisang kepok mampu menekan pertumbuhan Candida albicans.

Kandungan senyawa yang diduga dapat menekan pertumbuhan C. musae seperti flavonoid, tannin, saponin dan alkaloid juga terdapat dalam getah pisang. Teki menghasilkan senyawa metabolik berupa alkaloid, sineol dan minyak atsiri (Jawetz, dkk., 2008). Kesamaan senyawa yang terkandung dalam getah pisang dengan senyawa-senyawa yang diduga dapat menekan pertumbuhan dan sporulasi $C$. musae dalam ekstrak krinyu dan teki memungkinkan $C$. musae memiliki ketahanan terhadap senyawa-senyawa tersebut. Namun, perlu dilakukan penelitian lebih lanjut tentang aktifitas senyawa-senyawa tersebut terhadap jamur $C$. musae.

Penambahan ekstrak daun krinyu dan teki ke media PDA dapat mengendalikan pertumbuhan $C$. musae, karena terdapat senyawa atau bahan yang dapat menekan pertumbuhan dan sporulasi C. musae. Pada perlakuan teki fraksi alkohol dan teki tanpa fraksinasi hanya mampu menekan pertumbuhan $C$. musae dalam beberapa hari setelah inokulasi, selebihnya justru memacu pertumbuhan $C$. musae. Hal ini dikarenakan senyawa yang berperan sebagai nutrisi dan pemacu pertumbuhan $C$. musae lebih berperan dan mengakibatkan perlakuan teki fraksi alkohol dan teki tanpa fraksinasi memiliki pertumbuhan dan tingkat sporulasi yang lebih tinggi daripada perlakuan kontrol.

\section{KESIMPULAN}

Dari hasil penelitian dapat disimpulkan bahwa perlakuan ekstrak krinyu tanpa fraksinasi lebih efektif menekan pertumbuhan dan pembentukan spora $C$. musae baik secara in vitro maupun in vivo.

\section{DAFTAR PUSTAKA}

Cahyono, B. 2009. Pisang. Penerbit Kanisius. Yogyakarta. $78 \mathrm{hlm}$.

Dinastutie, R., P.Y.S. Sri dan Y.N.H. Dwi. 2015. Uji efektifitas antifungal ekstrak kulit pisang kepok (Musa acuminata $x$ balbisiana) mentah terhadap pertumbuhan Candida albicans secara in vitro. Majalah Kesehatan FKUB. 2(3) : 177178.

Gholib, D. 2009. Uji Daya Hambat Daun Senggani (Melastoma malabathricum L.) terhadap Trichophyton mentagrophytees dan Candida albicans. Berita Biologi. 9(5): 253-259.

Harborne, J.B. 1987. Metode fitokimia. Penuntun Cara Modern Menganalisis Tumbuhan. Edisi kedua. ITB. Bandung. Hal: 69-76.

Imam, M. 2011. Antioxidant activities of different parts of Musa sapientum L. ssp. sylvestris fruit. Journal of Applied Pharmaceutical Science. 1(10): 68-72.

Ismaini, L. 2011. Aktivitas antifungi ekstrak (Centella asiatica (L.)) urban terhadap fungi patogen pada daun anggrek (Bulbophyllum flavidiflorum Carr). Jurnal Penelitian Sains. Vol 14(1): 4750.

Jawetz, Melnick, dan Adelberg. 2008. Mikrobiologi kedokteran. EGC. Jakarta.

Kusumaningtyas, E.L., Sukmawati, dan E. Astuti. 2008. Penentuan golongan bercak senyawa aktif dari ekstrak n-heksan Alpinia galanga terhadap Candida albicans dengan bioautografi dan kromatografi lapis tipis. JITV. 13(4): 323-328.

Kristanti Alfinda Novi. 2008. Buku Ajar Fitokimia. Airlangga University Press. Surabaya. $174 \mathrm{hlm}$.

Ogbebor, O.N. dan Adekunle A.T. 2008. Inhibition of Drechslera heveae (Petch) M. B. Ellis, causal organism of bird's eye spot disease of rubber (Hevea brasiliensis Muell Arg.) using plant extracts. African Journal of General Agriculture. 4(1): 19-26.

Owolabi M.S., Ogundajo A., Yusuf K.O., Lajide L., Villanueva H.E., Tuten J.A., dan Setzer W.N. 
2010. Chemical composition and bioactivity of the essential oil of Chromolaena odorata from Nigeria. Rec.Nat.Prod. 4(1): 72-78.

Panggabean, I.R. 2009. Pengaruh tingkat konsentrasi ekstrak gulma siam (Chromolaena odorata) yang diaplikasikan dengan cara semprot dan oles dalam menghambat perkembangan gejala penyakit busuk buah kakao di lapang. Skripsi. Universitas Lampung. $63 \mathrm{hlm}$.

Prasetyo. 2008. Aktivitas dan uji stabilitas sediaan gel ekstrak batang pisang ambon (Musa paradisiaca var sapientum) dalam proses penyembuhan luka bakar pada mencit (Mus musculus albinus). Skripsi. Institut Pertanian Bogor. $58 \mathrm{hlm}$.
Rizky Ovi, A. 2012. Uji Daya Antifungi Ekstrak Etanol Daun Sirih Merah (Piper crocatum Ruiz \& Pav) terhadap Candida albicans ATCC 10231 secara In Vitro. Skripsi. Fakultas Kedokteran. Universitas Muhammadiyah Surakarta.11 hlm.

Semangun, H. 1996. Pengantar Ilmu Penyakit Tumbuhan. Gadjah Mada University Press. Yogyakarta. $754 \mathrm{hlm}$.

Wulansari, L. 2009. Kajian Ekstrak Pandan Wangi (Pandanus amryllifolius Roxb.) sebagai Repellent bagi Nyamuk Aedes aegypti. Skripsi. Fakultas Biologi. Universitas Jenderal Soedirman, Purwokerto. 